\title{
Identification of Basic Agility Movement Skills on Soccer Students of KU between 11-13 Years
}

\author{
Wahyu Wibowo Eko Yulianto \\ Faculty of Industrial Engineering \\ University of National Development Veteran \\ Yogyakarta \\ Yogyakarta, Indonesia \\ wahyuwey@gmail.com
}

\author{
Siswantoyo \\ Faculty of Sport Science \\ Yogyakarta state university \\ Yogyakarta, Indonesia \\ plc_fikuny@yahoo.com
}

\author{
R. Agung Purwandono Shaleh \\ Faculty of Social Science \& Political Science \\ University of National Development Veteran \\ Yogyakarta \\ Yogyakarta, Indonesia \\ Purwandono.agung@yahoo.co.id
}

\begin{abstract}
Soccer is a very complex sport which encompasses multiple aspects within. Some of which include; physical, technique, strategy, and mental factors. The physical factor is a major factor and one of the vital foundations of sport achievements. However, if the physical factor is good, all other corresponding factors can be well developed. This study aims to briefly identify the level of Agility of basic soccer skill Movement of student ranged between 11-13 years. This study applies the descriptive research with survey method. The research instrument used was the Agility Basic Movement APORI test. The study subjects are the soccer students from the 5 districts in the Yogyakarta special region and they totalled 143. The data analysis method was conducted using the percentage descriptive analysis. The study result shows that the Basic Agility Movement of soccer students between 11-13 years group is categorized as very low, comprised of $8 \%$ (12 players), categorized as low, comprised of $21 \%$ (30 players), categorized as medium it comprised of $34 \%$ ( 48 players) categorized as high comprised of $35 \%$ ( 50 players) and categorized as very high comprised of $2 \%$ (3 players). Based on average score which was 18.13 , it can be concluded that Basic Agility Movement of soccer students between 11-13 years was categorized as medium. This result was influenced by several factors, which are: technique, sprint speed, leg muscle quality, coach ability, the players and environments.
\end{abstract}

Keywords-soccer, identification, agility basic movement, Agility affecting factors

\section{PRELIMINARY}

Soccer is a very complex sport which contains many aspects within it. Some of which include; physical, technique, strategy and mental factors. The physical factor is one of the important factors and one of the foundations of achievement in sport. This is because technique, strategy and mental can be properly developed if the physical factor is good [1].

Peak performance in soccer is not generated incidentally, rather, it is as a result of a precise and proper athlete preparation, based on training programs organized in detail, gradually planned, objective and sustainable [2]. Monitoring of athlete ability is necessarily conducted [3]. The coach is expected to control the physical condition of the athlete, so that the weakness of the athlete can be detected early, and this data has become a potential problem that can affect the achievement or performance competitions. A coach is expected to have the competencies of a coach. The competencies are coaching license, background and personality competency [4].
As other sports do, soccer also requires the data of players' development. It was emphasized by Barreira who stated that "These should provide coaches with valuable information to optimise individual and team training programmes" [5]. The understanding of sports provides coaches with valuable information to optimize the training program of individuals and team.

Soccer requires a combination of technique, tactics, physical fitness, mental strength, and teamwork[6]. Football is a team sport characterized by repeated bouts of short duration high-intensity sprints in an endurance context which also requires the maintenance of skills throughout the match. The match duration is 90 min plus overtime (as needed) and split into two 45-min halves with a 15 -min break between halves (i.e., halftime)[7].

A good physical condition is required of every athlete, especially for sports that required a prolonged high performance, such as soccer. According to Sajoto, there are 10 types of physical condition component, those are: (1) Strength: endurance; (3) muscular power: (4) speed (5) flexibility: (6) Agility: 7 coordination (8) balance; (9) Accuracy; (10) reaction [8]. Bompa also added that the components of bio motors needed in soccer is speed, flexibility, strength, aerobic endurance and coordination [9].

Speed, power, agility and coordination are part of components of physical condition required to support the skill I soccer. Speed and agility affect the skill of dribbling to evade opponent players. Power and coordination is beneficial in jumping to get the ball.

The aforementioned physical conditions are considered need to be identified to measure players' skill or characteristic to help coaches arrange the training program. Furthermore, to obtain high quality players, physical components need to be prepared such as: size, speed, power, agility, coordination, endurance and [9]. To understand these skills, the coach requires a measurement tool suitable for identifying this aspect.

This instrument is a vital measurement tool needed by coaches to measure individual skill. Instrument to measure the physical condition and skill of soccer players is widely available, from circuit tests in a series form to find out body proportion, physical and playing, or test for each item. The 
Agility Basic Movement test (APORI) is a test which aims to find out physical skill especially agility, speed, coordination and power [11].

The competition between ASPROVE DIY aged between 11-13 years in the middle of 2018, a competition of representatives' winner from 5 districts was conducted. Each team plays 2 times daily. However, there were several notes which were recorded by the authors during this competition. The author focused on students' physical condition. From the field date, it seems that the players could still retain their physical conditions and play in one match conducted for $2 \times 10$ minutes; however, they experienced a significant decrease in second round. The players collided when they went head on head for the ball, they easily lost the ball when passing the opponent, easily fell when trying to avoid opponents and were weak in protecting the ball from the opponent.

On the other hand, the coaches are expected to be able to increase and develop players' skill and not just to fulfill their duties. On average, the coaches had a license level of D and a lot of coaches did not even have any license. This phenomenon was a hindrance in the development process of players' physical skill, the coaches mostly focused on technique and ignored physical exercise variation. Training physical strength is important because it is the foundation in the sport training pyramid to gain a peak achievement.

At the time of the competition, players still showed less fighting spirit, they made unnecessary mistakes like poor dueling and did not swiftly release themselves from the opponent's guard. This indicates that even the champions players of each city district were still lacking in maintaining their physical condition, especially in the player's agility skill.

Based on these data, the authors identified the basic agility skill of the players in the five city districts in the Special Region of Yogyakarta which also have demographics with their own characteristics. So, it can be used later as a basis for the coaches to determine the training program to properly develop the players physical skills.

\section{RESEARCH METHOD}

A. Type of study

This descriptive study was conducted to describe the collected data as it was [12]. The author used the survey method, meanwhile, the data collecting technique was the instrument using the agility basic movement test (APORI, 2014).

\section{B. Subject of study}

The sample was part of the number and characteristics possessed by the population, so the sample can be taken from a population [12]. The sampling in this study was conducted by total sampling and 143 football players were taken.

C. Research instrument

The data collecting instrument is a tool used by the researcher to collect the data in order to make the activity systematic and easen it [13]. The instrument used in this research was in form of the agility basic movement (APORI) test. The steps of test $\mathrm{m}$ assessment are explained as follow: 1) Aim

The Agility basic football movement test is used to determine physical abilities, especially agility, speed, coordination, and power. Football games require these four aspects to during the gameplay.

2) Equipment

$1.5 \mathrm{~m}$ high Stake, 14 pieces, $0.5 \mathrm{~m}$ high goal, 6 pieces, limestone, long meter, stopwatch

3) Procedure

a) The subject put on soccer shoes. b) The subject put sport shirts and pants

c) The subject stood by at the start line.

d) After the sign "ya" the subject ran with speed in accordance with the sign, passing the stakes and jumped over the goal and ran fast to the finish line.

e) Stopwatch was stopped after the Subject reached the finish line.

f) Every Subject conducted the test twice.

4) Assessment

Recording the fastest execution time from 2 attempts, from start to finish in seconds (recorded up to two digits of decimal)

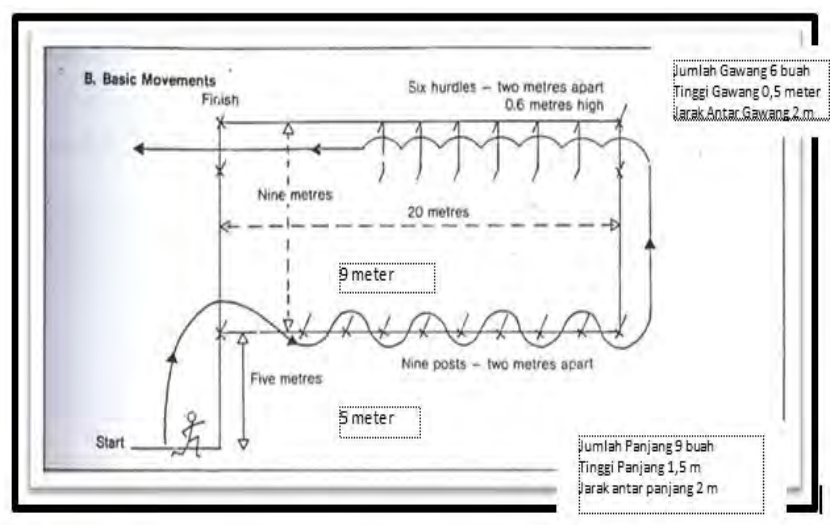

Fig. 1. Agility Basic Movement Test

\section{Data analysis technique}

The data analysis technique in this study was the quantitative descriptive data analysis technique. To calculate the percentage included in the category in each aspect used formula [14]:

$$
\mathrm{P}=\frac{f}{N} \mathrm{x} 100 \%
$$

Where:

$\mathrm{P}=$ Percentage number

$\mathrm{F}=$ The frequency of which the percentage is calculated

$\mathrm{N}=$ Number of Case

Determining the score criteria by using the Reference Norm of (PAN) [15] in the following scale:

TABLE I. NORM ASSESSMENT

\begin{tabular}{|c|l|c|}
\hline No & \multicolumn{1}{|c|}{ Interval } & Category \\
\hline $\mathbf{1}$ & $\mathrm{M}+1,5 \mathrm{~S}<\mathrm{X}$ & Very high \\
\hline $\mathbf{2}$ & $\mathrm{M}+0,5 \mathrm{~S}<\mathrm{X} \leq \mathrm{M}+1,5 \mathrm{~S}$ & High \\
\hline $\mathbf{3}$ & $\mathrm{M}-0,5 \mathrm{~S}<\mathrm{X} \leq \mathrm{M}+0,5 \mathrm{~S}$ & Medium \\
\hline $\mathbf{4}$ & $\mathrm{M}-1,5 \mathrm{~S}<\mathrm{X} \leq \mathrm{M}-0,5 \mathrm{~S}$ & Low \\
\hline $\mathbf{5}$ & $\mathrm{X} \leq \mathrm{M}-1,5 \mathrm{~S}$ & Very low \\
\hline
\end{tabular}

\section{STUdy RESUlT}

\section{A. Result Description}

The data to identify the basic mobility capabilities of soccer school players aged 11-13 years used the Agility Basic Movement APORI test.

From the data analysis of the Basic Agility Movement of soccer school players in the group, was lowest (minimum) score obtained was 15.12, the highest (maximum) score was 23.10 , average (mean) was 18.13 , median was 17,86 , the most frequent data (mode) 17.50, standard deviation (SD) 1.67. 
Frequency distribution is shown in table 2 below:

TABLE II. ASSESSMENT OF NORM VALUES

\begin{tabular}{|c|c|c|c|}
\hline No & Interval & F & Very high \\
\hline $\mathbf{1}$ & $15.62<\mathrm{X}$ & 3 & High \\
\hline $\mathbf{2}$ & $15.62<\mathrm{X} \leq 17.29$ & 50 & Medium \\
\hline $\mathbf{3}$ & $17.29<\mathrm{X} \leq 18.97$ & 48 & Low \\
\hline $\mathbf{4}$ & $18.97<\mathrm{X} \leq 20.65$ & 30 & Very low \\
\hline $\mathbf{5}$ & $\mathrm{X} \leq 20.65$ & 12 & Very high \\
\hline \multicolumn{2}{|c|}{ Total } & 143 & \\
\hline
\end{tabular}

When displayed in a graphical form, the data on the level of Basic Agility Movement Ability of SSB Students aged 1113 Years is shown in the following graph:

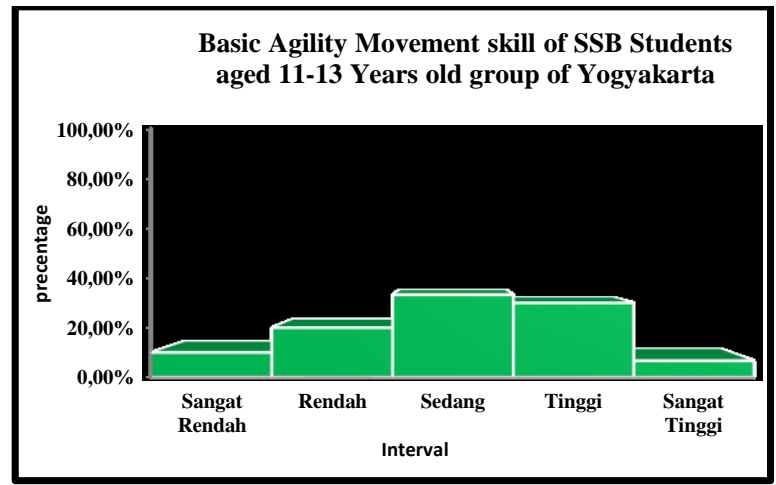

Fig. 2. Diagram of Agility Basic Movement skill of SSB Students aged 1113 Years of Yogyakarta.

Based on the table and graph above, the Basic Agility Movement Ability of 11-13 Years Old Students of SSB in the category of "very low" was $8 \%$ (12 players), category of "low" was $21 \%$ (30 players), category of "medium" was $34 \%$ (48 players), the "high" category was $35 \%$ (50 players), and the "very high" category was $2 \%$ (3 players). Whereas, based on the average value of 18.13, the Basic Agility Movement skill of SSB Students aged 11-13 years old group was in the "medium" category.

If the Agility Basic Movement skill of SSB Students aged 11-13 Years is displayed in graphical form each city district, it can be seen as:

\section{Sleman District}

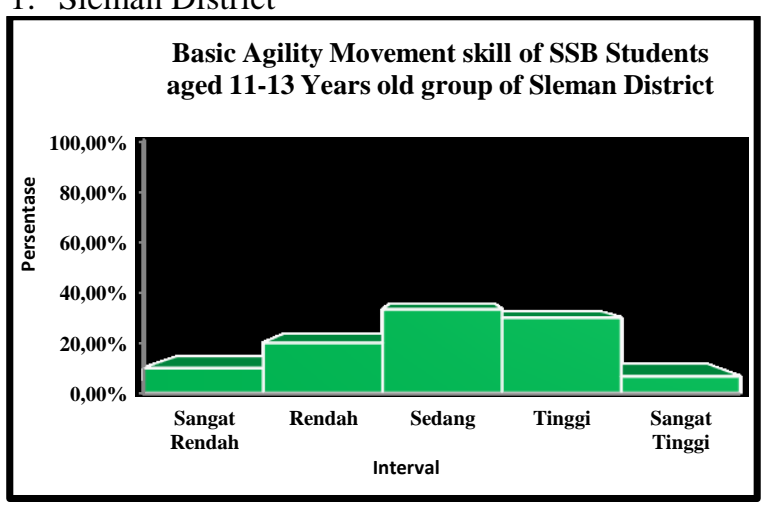

Fig. 3. Diagram of Basic Agility Movement skill of SSB Students aged 11-13 Years of the Sleman District
Based on the graph above, the Basic Agility Movement skill of SSB Students aged 11-13 Years was in the "medium" category.

2. City district

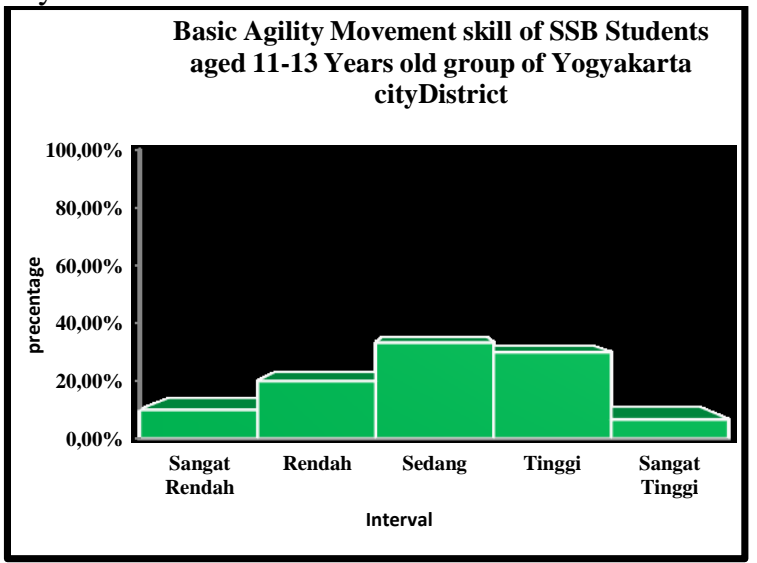

Fig. 4. Diagram of Basic Agility Movement skill of SSB Students aged 11-13 Years of Yogyakarta cityDistrict

Based on the graph above, the Basic Agility Movement skill of SSB Students aged 11-13 Years was in the "medium" category

\section{Bantul District}

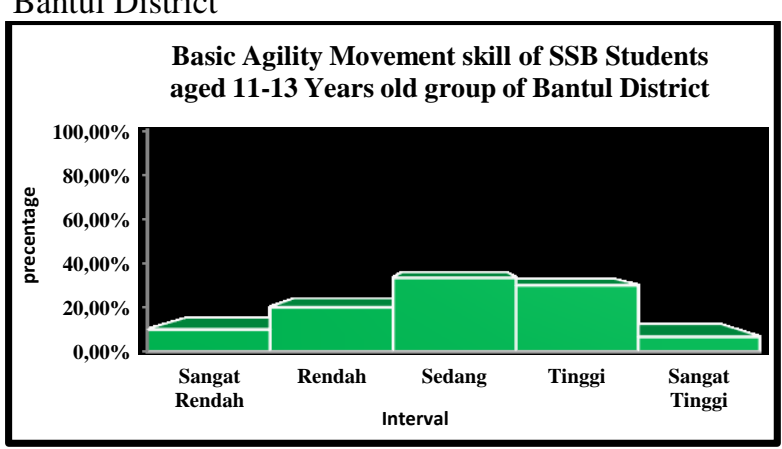

Fig. 5. Diagram of Basic Agility Movement skill of SSB Students aged 1113 Years of Bantul District

Based on the graph above, the Basic Agility Movement skill of SSB Students aged 11-13 Years was in the "high" category.

4. Gunung Kidul District

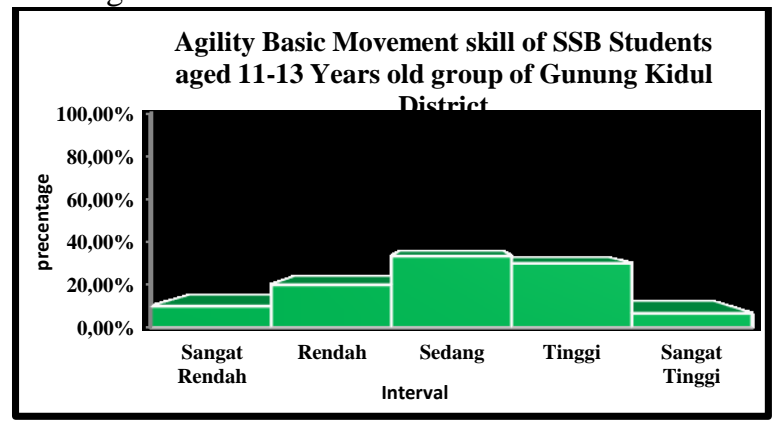

Fig. 6. Diagram of Basic Agility Movement skill of SSB Students aged 1113 Years of Gunung Kidul District 
Based on the graph above, the Basic Agility Movement skill of SSB Students aged 11-13 Years was in the "medium" category.

\section{Kulon Progo District}

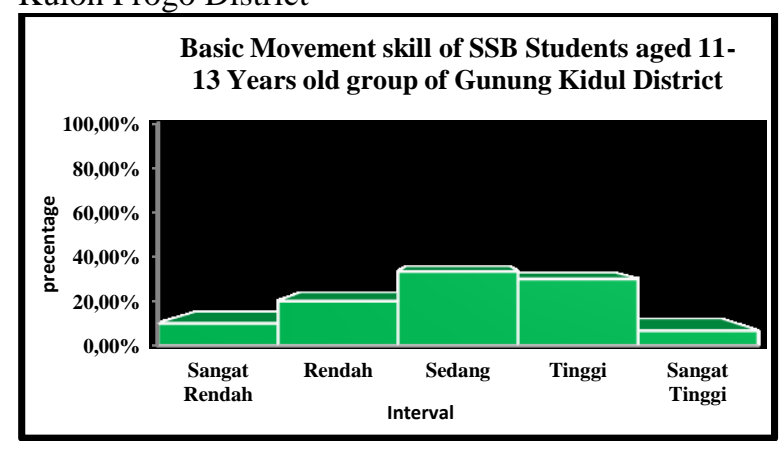

Fig. 7. Diagram of Basic Agility Movement skill of SSB Students aged 1113 Years of Gunung Kidul District

Based on the graph above, the Basic Agility Movement skill of SSB Students aged 11-13 Years was in the "medium" category.

\section{B. Discussion}

Top performance in soccer is not created coincidentally; rather it results from the careful preparation of athletes based on an organized training program in great detail, planned in steps, objective and sustainable [2]. Monitoring the ability of athletes is very necessary [3]. The coach should record the initial physical condition of the athlete, so that the weakness can be detected early and the data will become a guideline in the training process.

Agility is the ability to change direction and position of the body or its parts quickly and precisely [16]. In football, agility is very necessary in dribbling techniques to be able to create proper breakthroughs, avoid or escape the guarding opponent, or to pass opponents who block players.

Based on the results of the study, the average of Basic Agility Movement skill for SSB Students aged 11-13 years was in the medium category. Of the 5 regencies, the Bantul district shows the Basic Agility Movement skill in the high category, while the other 4 SSBs from other districts were in the medium category.

The direction of the change of speed is influenced by three major components, which are 1) Technique, 2) sprint speed and 3) leg muscle quality [17]. The results of the study indicate environmental differences between football schools in the five districts in Yogyakarta Special Region. Environmental factors can affect the ability to move, physiological changes and acclimatization of training [18]. The Bantul district with coastal demographics shows that players' agility skill on average was in the high category.

The coach factor has an important role in developing player skills. The coach is like a building architect [19], so the coach is expected to have competencies as a coach. These competencies are training licenses, training backgrounds, personality competencies [4]. Furthermore, the coach must also have the following requirements: (1) Ability and skills in sports, (2) Knowledge and experience in their fields, (3) Dedication and commitment to train, (4) Good morality and personal attitude [20].

The results of the study describe that the license and coaching background must be gradually increased by the coach in order to improve competence in terms of preparing training programs. Background or training experience also greatly influences how coaches manage the training process. The personality of the Coach is also important. A coach must be able to teach and develop character in a training atmosphere [21] and a person of character embodies both performance character and moral character [22], motivational abilities, technical skill and ability to implement strategies in matches.

Factor The concept of being described is an individual's picture of him; includes physical, social, psychological, emotional, aspirational, and achievement characteristics. " Motivation from achievement as a person orations to strive for task success, persists in the face of failure, and experience pride in accomplishments" [23]. Motivation from achievement provides an opportunity for athletes to achieve something perfectly, improve fitness at the highest level, and practice optimally.

\section{CONCLUSION}

The results showed that Agility Basic Movement skill for SSB Students aged 11-13 years categorized as "very low" was $8 \%$ (12 players), the "low" category was $21 \%$ (30 players), "medium" category was 34\% (48 players), "high" category was $35 \%$ (50 players), and "very high" category was $2 \%$ (3 players). Based on the average value of 18.13, it can be concluded that the ability of Basic Agility Movement for SSB students aged 11-13 years was in the medium category. This result is affected by several factors, which include: technique, sprint speed, foot muscle quality, coach, players them self, and player's environment.

\section{REFERENCE}

[1] P. Irianto Dasar kepelatihan. Yogyakarta: UNY Press, 2002

[2] Harsuki. Perkembangan olahraga terkini kajian para pakar. Jakarta: Rajagrafindo Persada, 2003

[3] T. Haugen, and S. Seiler, "Physical and physiological testing of soccer players: why, what and how should we measure?," 2015. Oslo: University of Agder (sportscience.org)

[4] U. Rahman. "Evaluasi koompetensi pelatih sepak bola usia dini di sekolah sepakbola," Jurnal Penjas, Volume 9, Nomor 2, 92-104. 2017. http://ejournal.upi.edu/index.php/penjas

[5] D. Barreira, "SoccerEye: A software solution to observe and record behaviours in sport settings," The Open Sports Science Journal. Porto:

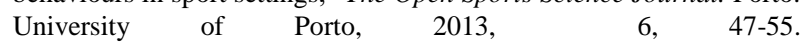
https://benthamopen.com/contents/pdf/TOSSJ/TOSSJ-6-47.pdf

[6] Asai \& Taga. The influence of short term intensive dribbling training on ball skill. Footbal Science, 2011, Vol. 9. 35-49. www.shobix.co.jp/jssf/journal/2012/038

[7] O. Laitano, "Hydration science and strategies in football." Sports Science Exchange, Vol. 27, No. 128, 1-7, 2014

[8] M. Sajoto Peningkatan dan pembinaan kekuatan kondis fisik dalam olahraga, Semarang, Dahara Prize, 1999 
[9] T. O. Bompa Theory and methodology of training. The Key to Athletic Performance, $3^{\text {rd }}$. Dubuque. Lowa: Kendal/Hunt Publishing Company, 1994

[10] J. Brown, Sports talent, how to identify and methodology of training: Fourth Edition. United States. Human Kinetics, 2001

[11] APORI. Panduan identifikasi bakat istimewa olahraga sepakbola, bolavoli, bulutangkis, pencak silat. Yogyakarta: Direktorat Pembinaan PK-LK DIKDAS KEMENDIKBUD RI, 2014

[12] Sugiyono. Metode penelitian kuantitatif, kualitatif dan $R \& D$, Bandung:Alfabeta, 2009

[13] S. Arikunto . Prosedur penelitian, suatu pendekatan praktek, Yogyakarta: Andi offset, 2006

[14] A. Sudjono, 43 Anas Sudijono. (2009). Pengantar evaluasi pendidikan. Jakarta: PT Raja Grafindo Persada. 2012:

[15] S. Azwar. Sikap manusia teori dan pengukurannya. Yogyakarta: Pustaka Pelajar, 2010

[16] Ismaryati. Peningkatan kelincahan atlet melalui penggunaan metode latihan sirkuit plyometrik dan berat badan. Paedagogia, 11 (1), 74-89, 2008.

[17] J. Doty Sport building character., Journal of College and Character. 7(3), hlm. 1-20, 2006

[18] D. Mathew Developing performance character and moral character in youth, the fourth and fifth rs respect and responsibility, Journal of College and Character. 10(2). ), hlm. 1-6, 2004

[19] Wangmuba. Konsep diri. [Online]. Tersedia:http://wangmuba.com (Diunduh 20 Juni 2018).

[20] W. Young, and D. Farrow, "A review of agility: practical applications for strength and conditioning," () National Strength and Conditioning Association. Volume 28, Number 5, pages 24-29, 2006

[21] E. L. Fox, R. W. Bowers, M. L. Foss, "The physiological basis for exercise and sport" 5th.Ed. Boston USA. WCB/McGraw Hill. 1993.

[22] W. Young, and D. Farrow, "A review of agility: practical applications for strength and conditioning," () National Strength and Conditioning Association. Volume 28, Number 5, pages 24-29, 2006

[23] E.L Fox, R.W Bowers, M.L Foss The physiological basis for exercise and sport. 5th.Ed. Boston USA. WCB / McGraw Hill. 1993. 